\title{
GIVING WOMEN A VOICE THEY NEVER HAD: COMMUNITY RADIO
}

\section{MIHIKA SENGUPTA}

Research Scholar, Faculty of Media Studies and Humanities, Department of Journalism and Mass Communication,

Manav Rachna International Institute of Research and Studies, Faridabad, Haryana, India

Having a finger on the pulse of one's region is not an easy job, especially if that one is a woman. Alike, it wasn't an easy ride for Shukla, Koshti, Gandhimathi and many others like them. But now, they rule the airwaves via Community Radios (CR), which broadcasts programs in regional languages to respective villages. Women have always made their mark in every sphere of life that even $C R$ is not alien to this. There are over $400 \mathrm{CR}$ stations presently in India, out of which many are run for/by women in rural areas. CR is a participatory tool for communication which provides a platform to create awareness, provide information and education, improve skills or empower.

By examining the opportunities for and challenges faced by women who participate in CR, this study offers insights into how CR has the potential to reshape the lives of women.

This research aims to do content analysis of five CR stations and will be analyzed on how they gain a voice that matters and also, how they enhance the inclusion of women in CR. Written as a crossover between gender and CR, the author looks at how the CR movement, policy and practice in India act as a tool for rural women development and proves to be an instrument in changing their lives.
\end{abstract}

KEYWORDS: Community Radio, Empowerment \& Rural Areas

Received: Apr 27, 2019; Accepted: May 18, 2019; Published: Jun 08, 2019; Paper Id.: IJCMSJUN201918

\section{INTRODUCTION}

Community Radio (CR) has its unique value in the society. It provides a platform where members of a community or communities can discuss their problems, issues and exchange views. It develops a sense of belonging among the members of a community. Community Radio is a radio for the development of the particular community people within the geographical limits of that area. It is a non-profitable organization and the radio programs are volunteered by the community people. They give psychological support, to build solidarity and rebuilt the knowledge and behavior of the community people. It's a third type of radio broadcasting apart from public and commercial or private radio broadcasters. CR plays a crucial role in creating awareness among people and informing citizens about their rights and entitlements. UNESCO says that as radio continues to evolve in the digital age and remains the medium that reaches the widest audience worldwide. This multi-purpose medium can help people to engage in discussions on topics that affect them. Community radio is recognized as one of the most low cost media, especially suitable to reach remote communities and disadvantaged group of people- the illiterates, the disabled, women, youth and the poor, while offering a platform to intervene in the public debate, irrespective of people's educational level (Dutta \& Ray). The philosophy of community radio is to use this medium as voice of the voiceless and the mouthpiece of the oppressed people and as generally as tool for development. It often reflects the gender stereotyping of mainstream radio stations in staff and volunteer roles, despite having aims and charters that 
support equal opportunities and it attracts the women as the volunteers. Being a participatory communication medium, Community Radio can be instrumental in making the voices of the underprivileged and marginalized sections of society heard, one such section being Women. India remains the land of extreme patriarchal influence, women having little control over their bodies and lives, especially in rural areas. In the struggle to empower women to take control over their lives, community media plays a significant role, evolving women into positive deviants (Gaur, 2016).

Accordingly, this paper focuses on how CR provides an opportunity for women's access to information and allows them to break through the shackles of patriarchy and have their voices heard. By examining the opportunities for women who participate in CR, this study offers insights into how CR has the potential to reshape the lives of women by introducing shows and programs for them, based on daily issues and offer solutions. Written as a crossover between gender and CR, the study looks at how the CR movement in India acts as a tool for rural women development and proves to be an instrument in changing their lives.

\section{REVIEW OF LITERATURE}

\section{Community Radio in India}

"It is called popular or educational radio in Latin America, rural or local radio in Africa, public radio in Australia and free or associative radio in Europe. All these describe the same phenomenon - gaining voices and democratizing communication on a community / scale. Community radio, although taking on diverse forms depending on its surroundings, remains a type of radio made to serve people; radio that encourages expression and participation and that values local culture. Its purpose is to give a voice to those without voices, to marginalized groups and to communities far from large urban centers, where the population is too small to attract commercial or large-scale State radio."

- Michael Delorme, World Association of Community Broadcasters

$\mathrm{CR}$ is a relatively young sector in India. Though the campaign to legitimize community radio began in the mid 1990s, the CR Policy that enables not-for-profit organizations to apply for license was not enacted by the Ministry of Information and Broadcasting (MIB) until 2006. The Policy was as an outcome of the longstanding demands of the CR movement, which developed from 1995 when the Supreme Court of India ruled that, "airwaves constitute public property and must be utilized for advancing public good." The movement, which in 2007 was institutionalized with the establishment of Community Radio Forum (CRF), shed light on the necessity to develop a third alternative to the Stateowned and private media to cater to local audiences' and grassroots development needs, which were absent in public broadcasting and commercial stations. Indeed, although state-owned All India Radio (AIR), through a capillary network of local stations, has been traditionally used as a tool in support of the national development effort, its top-down approach and centralized editorial system hinder it from addressing communities' communication needs. Although CR Policy was ratified only recently in India, the use of radio as a tool of participatory development has a longer history. The first evidence dates back to 1956, when 150 villages in Maharashtra were invited to discuss about AIR local radio content through the UNESCO-facilitated Farm Radio Forum. Also, some grassroots NGOs - Kutch Mahila Vikas Sangathan (KMVS) in Gujarat; Alternative for India Development (AID) in Jharkhand, Deccan Development Society (DDS) in Andhra Pradesh and Mysore Resettlement and Development Agency (MYRADA) in partnership with VOICES in Karnataka - pioneered CR initiatives in the 1990s with the production of radio programs, which were either broadcast through local AIR frequencies or distributed through alternative methods such as cable and narrow-casting (Nirmala, 2015). 


\section{Role of Community Radio's in Women Empowerment}

Empowerment is essentially a transition from a position of enforced powerlessness to one of power. It promotes women's inherent strengths and positive self-image. Gaining power means acquiring ability and opportunity to participate and contribute in the social development process creatively and meaningfully. The process of empowerment enables them to develop in them self-dignity. It enables them to raise voice and fight against injustice, exploitation, abuse, and violence done to them (Nirmala, 2015).

Radio has been discussed as a female medium in terms both of the intimate relationship women have with it as listeners and of the program content that has been devised by/ for them. Radio is a medium which is women friendly, pertinent and accessible in terms of learning the production skills and techniques, working together to shape program schedules and tell their stories to help them regarding the needs of information, education and pleasure through the wide range of programming forms(Rikzana \& Neelamalar, 2015).

Across India, several CR stations are tapping the potential of women for their programming and also involving them in decision-making making roles. Many NGOs - such as DDS, Andhra Pradesh; KMVS, Gujarat; Self Employment Women's Association SEWA, Gujarat; and Mann Deshi Foundation, Maharashtra have set up CR stations that are run exclusively by women. These stations have helped in amplifying the voice of marginalized rural women, and many women caught up within feudal social structures are beginning, albeit slowly, to find a voice of their own (Malik \& Bandelli, 2012).

Apart from these, there are also CRs that may not be run by women exclusively but have women as anchors, content contributors and produce content for women development. The Namma Dhwani community radio enhanced the participation of women in program production and created awareness among the women listeners about health and sanitation, education, food habits and family system and significant change was happened in the lives of women. Mandeshi proved to be useful to the listeners (mostly for women) in their life. It increased their knowledge and enabled them to showcase their talent and motivated them on various issues including education, health etc. Anna University played an important role in social, economic, and political empowerment of women. When it comes to social empowerment it happened in terms of knowledge and skill development, in terms of political empowerment i. e. knowing the Panchayat representative, voting in assembly and general elections etc. Holy Cross Community radio proved to build women's selfconfidence, generated awareness about pollution, health and hygiene and helped in their personality development. Puduvai Vani enhanced the four aspects of women (listeners and reporters through their participation and listening). They include psychological, economic, cultural, political and social. Women, both reporters and listeners, have started to reflect on their abilities and aspirations and on other women's life; their capabilities to produce communicative acts in future, through media and at an interpersonal level, seem to be stronger; they have acquired confidence in speaking in public and in challenging discriminatory traditions; their ability to make informative choices is enhanced by an improved access to a vast array of information, including women's rights; they have also acquired or improved writing skills and familiarized with Information Technology and media; their consideration within family and community has improved(Nirmala, 2015).

\section{METHODOLOGY}

One of the major aims of this research is to study how CRs have helped empowering and educating women through their shows/programs on issues relating to women and their daily lives. Thus, for the same I used Content 
Analysis. This method is relevant in this study because it enables researcher to develop an insight into the types of programs broadcast and further, its use by and for women. The CR's have been selected randomly from each zone of India i. e. North, East, West, South and Central. They have been listed down below in Table1. The study is mostly based on Secondary Source: a Journal named "Community Radio for Change" by Young India and Action Aid, along with some reports and websites.

Table 1: Community Radio's Selected for this Study

\begin{tabular}{|c|c|c|c|c|c|}
\hline $\begin{array}{c}\text { Serial } \\
\text { No. }\end{array}$ & Zone and State & $\begin{array}{l}\text { Community } \\
\text { Radio Name }\end{array}$ & $\begin{array}{l}\text { Operating } \\
\text { Since }\end{array}$ & Operated by & Working Idea \\
\hline 1 & North-Uttar Pradesh & $\begin{array}{l}\text { Waqt Ki Awaz } \\
\text { 91.2 FM }\end{array}$ & $\begin{array}{c}25^{\text {th }} \text { September } \\
2013\end{array}$ & $\begin{array}{l}\text { Shramik } \\
\text { Bharti }\end{array}$ & $\begin{array}{l}\text { Open defecation } \\
\text { alcohol addiction, } \\
\text { elderly people, girl } \\
\text { education, diseases }\end{array}$ \\
\hline 2 & West-Gujarat & $\begin{array}{l}\text { Rudi Na Radio } \\
\text { 90.4 FM }\end{array}$ & $\begin{array}{c}26^{\text {th }} \text { November } \\
2009\end{array}$ & $\begin{array}{l}\text { Kutch Mahila } \\
\text { Vikas } \\
\text { Sangathan }\end{array}$ & $\begin{array}{l}\text { Issues that affect } \\
\text { women, as women and } \\
\text { as labourers }\end{array}$ \\
\hline 3 & $\begin{array}{c}\text { Central- } \\
\text { Maharashtra }\end{array}$ & $\begin{array}{c}\text { Green Community } \\
90.4 \mathrm{FM}\end{array}$ & $\begin{array}{c}22^{\text {nd }} \text { August } \\
2010\end{array}$ & $\begin{array}{l}\text { Sasneha Kala, } \\
\text { Krida, \& } \\
\text { Sanskrutik } \\
\text { Mandal }\end{array}$ & $\begin{array}{l}\text { Issues that affect rural } \\
\text { people and their lives }\end{array}$ \\
\hline 4 & East- Odisha & $\begin{array}{l}\text { Radio Dhimsa } \\
\text { 90.4 FM }\end{array}$ & July 2008 & $\begin{array}{l}\text { Indian } \\
\text { institute of } \\
\text { education \& } \\
\text { care }\end{array}$ & $\begin{array}{l}\text { Provides voice for } \\
\text { voiceless and caters to } \\
\text { the issues of } \\
\text { community and current } \\
\text { affairs. }\end{array}$ \\
\hline 5 & South-Bangalore & $\begin{array}{c}\text { Radio Universal } \\
\text { 106.8 FM }\end{array}$ & $\begin{array}{l}21^{\text {st }} \text { June } \\
2008\end{array}$ & $\begin{array}{l}\text { Universal } \\
\text { Educational } \\
\text { Trust }\end{array}$ & $\begin{array}{l}\text { Issues and matters of } \\
\text { Art, Culture, Education, } \\
\text { Health, Empowerment, } \\
\text { Entertainment }\end{array}$ \\
\hline
\end{tabular}

The sample size that I have chosen belongs to community radios in India that has been introduced and discussed in the literature review. In addition to this, these CR's were chosen as a sample size for a number of reasons; first, all the selected stations are either run by women or have women as staff members and secondly, these stations run and introduce programs mostly to empower and educate people, mainly women, belonging to rural areas.

\section{Analysis of Community Radio's in India}

\section{North Zone - I}

\section{Waqt Ki Awaz's Program on Empowering Women against Open Defecation}

In rural areas, mostly, women are compelled to wait till nightfall or early morning to defecate, which not only instigates health risks but also risk of life and violence. Keeping this in view, Waqt Ki Awaz started this program named, "Ghar Ki Lutiya Khet Na Jaihe", which literally means "Small jugs from the home won't go to the farm". The said program raised and initiated discussion on: -

- It helped to make rural people aware about the health problems women face because of open defecation

- It also drew special attention to the issues of safety and dignity of women due to open defecation

- It made people aware about bathroom facility for women within the household

- It even talked about how bathing and defecating in the open gives rise to privacy issues 
- It stressed on how village girls are made to drop out of school/college once they start menstruating due to lack of toilet facilities in educational institutions

While researching for the program it was found that many women, children and aged people avoided food to keep away from toilet calls at night, more during winter and rainy seasons. Problem arises more when they felt shy to share this problem with anyone and more so, no one ever asked them about it. To only add up to this situation, women were always in tension because they had to dispose of faces of children and aged people of their family at night in remote areas alone.

The series not only discussed the problems but provided a solution for the same. They suggested appropriate toilet technology in low cost toilets. Not only women but they had also been successful in starting a discussion among the men of the community on issues related to sanitation. Even young boys got sensitized about the sanitation problems that their mothers, sisters and friends faced, and above all they even convinced, sometimes even forced their elders for the construction of toilet in respective houses.

\section{West Zone - II}

\section{Rudi No Radio's Program on Augmenting Livelihood for Better Women's Health}

In villages, life is very difficult. A family cannot be dependent solely on only farming or any kind of labour work. In rural areas, where women are mostly indulged in farming and domestic chores, Rudi Na Radio initiated a program for them named, "Satvik Jeevan", which literally means "Righteous Life". This program, initiated conversation on: -

- It made them aware of healthy and a good lifestyle

- It gave them information on organic farming and kitchen garden and how can they use it for improving their livelihood

- It also provided them with idea as to how they can use this for self consumption purpose

- It helped them to know how to use this method in increasing their income

Women had never thought that a small space in their house could be utilized for kitchen garden. They being the ruler of kitchen, life changed for many women post the program, who started kitchen garden in their house. Some of the ladies who had a pre-conception that proper land are required for farming, after the program started growing vegetable for self consumption. Moreover, those of who had cattle started using cow dung for more fertile land. They started selling the surplus vegetables in the market to increase their income.

Many awareness sessions and trainings were conducted on organic farming and kitchen garden where many listeners, mostly housewives, attended to learn the new techniques. Those who couldn't attend the awareness program listened to the broadcast. The expert team of Rudi No Radio also regularly visited the houses to monitor their farm \& make corrections whenever required. This helped the people to connect to the program more. This program had helped not just one woman but scores of women of the villages.

\section{Central Zone - III}

\section{Green Community Radio's Program on Creating a Comfortable Society for Women in Period}

In rural areas, mostly, women are treated as untouchables, compelling them to live alone in a room, other than their own, whenever they menstruate. They are not provided proper sanitation which not only instigates health risks but 
also risk of life. Keeping this in view, Green Community Radio started this program named, "The Unacceptable Truth Menstruation”. The said program raised and initiated discussion on: -

- It created awareness among the people, both men and women on the topic of Menstruation

- It drew special attention of people who did not accept the fact that menstruation is a natural process which a girl goes through every month after reaching adolescence

- It also instigated women to speak about their periods without getting ashamed of it

- It even encouraged women to be open about their health issues and problems

Since women in rural areas face problem when they are in there periods, it was an amazing initiative to bring awareness and make the society accept it as a natural occurrence. Interviews of gynecologists and a few lectures conducted by them on the same, helped in educating rural people on menstruation. Interviews with women who were on their periods at that time were also conducted to get real time experiences. Moreover, the Rj's, did field visits by visiting rural schools and colleges. The uniqueness of the program was in bringing such a topic into discussion in the villages and making women feel comfortable while talking about and on periods.

\section{East Zone - IV}

\section{Radio Dhimsa's Program on Empowering Women for Good Governance}

For women, having a voice of their own and a representation of their own is very rare in rural areas. Being dominated every time and everywhere by the men in their lives makes them gullible and aloof. Being a human being, they have an equal right at life and decisions as their fellow men. Thus, to make this possible, Radio Dhimsa launched a program titled, “Amar Sopon Su Sasan", which literally means, "My dream is good governance”. Designed for mothers, young girls\& women of age group between 25 - 40 years old from tribal villages, this program started conversations on: -

- It highlighted the achievements \& accomplishments of women SHGs, individuals and young girls

- It focused on bringing equality among the genders in villages

- It made special efforts to allow the voices of women to be heard in Gramsabhas \&Palli Sabhas

- It created awareness for women on government acts, rules, schemes of programs

The rights conferred under PESA were not reaching the people, especially women who are dominated in tribal societies and this is what gave birth to a program of such repute. The aim of the program was that rights should flow to women to have an equitable society not only on paper but also in the field. Like the name, the program sought to preach good governance by targeting tribal women. Tribal women block chairpersons, vice chairpersons spoke of their experience in the Panchayat Raj system and this sharing of working experiences helped new elected representatives to polish their skills in good governance and also encouraged other women to take up challenges and put forward their opinions and ideas being fearless. It was reported that at first it was very difficult to hold a discussion on rights to women in front of men in the village and many a times violent situation were created by men who with passage of time got mellowed down.

The program not just pointed out problems but also corrected them. As per the report of the Child line, the average age of marriage of women increased because of decision making by women. Women have started having a say in 
financial matters in the family which was unheard of. The program has not only empowered women but has ushered in good governance in the villages with more women participating in the process.

\section{South Zone - V}

\section{Radio Universal's Program on Promoting Young Women for Participation}

Women's empowerment has always remained a not so important topic, more so in the rural areas. What people don't understand is that if women are not empowered then the whole system of life shall shut down. Thus, prioritizing women's opinion and say became one of the most important issues to be discussed for Radio Universal, which on the same line initiated a program named, “Oh Gelathi?”, which literally means, “Oh Woman?”. The said program initiated discussions on: -

- It created awareness amongst people for empowering women in India

- It reinforced the idea that women can not only be harbinger of change but also tough decision makers

- It addressed and discussed about many social barriers that women face in the society to establish themselves.

- It explored the area of women's safety \& security in India

Women not only constitute almost half the population of this country but are important members of the family as are others. The program encouraged people, especially women from all walks of life to participate \& share their skills, knowledge \& experience to inspire young people. It put across the idea that together with men, they can create a just $\&$ equitable society. Women who are already employed were particularly encouraged to speak in the show to inspire other young women so that they know how to face obstacles when wanting to get into mainstream work. Experts also shared tips on social skills, positivity, communication \& collaboration to polish the skills of the target group. The program also supported training and employment for women, which in turn benefitted a many. Lastly, it also ensured increased participation of women in different fields in the region.

Table 2: Summary Table of the Programs

(Young India, 2017)

\begin{tabular}{|c|c|c|c|c|c|}
\hline Crstation & $\begin{array}{c}\text { Total } \\
\text { Time }\end{array}$ & $\begin{array}{c}\text { Coverage Area } \\
\text { (CRS) }\end{array}$ & $\begin{array}{c}\text { Name of } \\
\text { Program }\end{array}$ & $\begin{array}{c}\text { Duration of } \\
\text { Program }\end{array}$ & $\begin{array}{c}\text { Transmission of } \\
\text { Program }\end{array}$ \\
\hline $\begin{array}{c}\text { Waqt Ki } \\
\text { Awaz }\end{array}$ & 9 Hours & 303 Villaes & $\begin{array}{c}\text { Ghar Ki Lutiya } \\
\text { Khet Na Jaihe }\end{array}$ & $\begin{array}{c}30 \text { Mins (15 } \\
\text { Prog }+15 \\
\text { Interaction) }\end{array}$ & $\begin{array}{c}07: 20 \mathrm{am}-07: 50 \mathrm{am} \\
\text { Repeat-01:25pm- } \\
01: 55 \mathrm{pm} \text { And } \\
07: 05 \mathrm{pm}-07: 20 \mathrm{pm}\end{array}$ \\
\hline $\begin{array}{c}\text { Rudi Na } \\
\text { Radio }\end{array}$ & 8 Hours & $\begin{array}{c}\text { Sanand Village, } \\
\text { Ahmedabad }\end{array}$ & Satvik Jeevan & 15 Minutes & $\begin{array}{c}12.30 \mathrm{pm} \\
\text { Twice a day }\end{array}$ \\
\hline $\begin{array}{c}\text { Green } \\
\text { Community } \\
\text { Radio }\end{array}$ & 17 Hours & 10 Km Radius & $\begin{array}{c}\text { Unacceptable } \\
\text { Truth }- \\
\text { Menstruation }\end{array}$ & 30 Minutes & $\begin{array}{c}10.00 \mathrm{am}-10.30 \mathrm{am} \\
\text { Only Sundays }\end{array}$ \\
\hline $\begin{array}{c}\text { Radio } \\
\text { Dhimsa }\end{array}$ & 9 Hours & 60 Villages & $\begin{array}{c}\text { Aamorsapan Su } \\
\text { Sasan }\end{array}$ & 30 Minutes & $\begin{array}{c}\text { 9.30am-10.00am } \\
\text { Thrice A Week }\end{array}$ \\
\hline $\begin{array}{c}\text { Radio } \\
\text { Universal }\end{array}$ & 6 Hours & $\begin{array}{c}\text { Vijaynagara, } \\
\text { Tollgate }\end{array}$ & Oh Gelathi & 1 Hr & $\begin{array}{c}10.00 \mathrm{am}-11.00 \mathrm{am} \\
3.00 \mathrm{pm}-4.00 \mathrm{pm}\end{array}$ \\
\hline
\end{tabular}




\section{Post Analysis Understandings}

After analyzing programs five of CR stations that not only have women as staff members but also try to focus and make programs on issues related to women, it can be stated that they have successfully created awareness about everyday problems faced by women in their community and have also provided solutions on how those problemscan be evaded. While Rudi Na Radio enhanced the participation of women in program production and created awareness among the women listeners about augmenting their lifestyle by using kitchen garden which shall lead to a significant change in their daily lives, Radio Universal proved to be useful to the listeners in motivating them on various issues such as good governance and active participation in gram sabhas. Radio Dhimsa for its part played an important role in social, economic, and political empowerment of women in its area. In terms of political empowerment, it helped them get to know the Panchayat representatives, to enable them to vote in the general elections. Whereas on the other hand, Waqt Ki Awaz and Green Community Radio educated and informed women on the problems related to open defecation and menstruation respectively.

The analyzed radio programs have brought various changes and created more awareness among women. They have even improved the standard of living of women in the society. What is understood from the analysis is that there can be three ways of empowering and involving women with community radios; one is to put up radio stations run by women, second, is to put up shows for women and third is to involve women as listeners. Some of the aims of these stations and their programs were to train interested community members, especially illiterate and semi-literate women to use technology to talk about their daily issues, their struggles, their achievements and also to provide the women listeners with a way of connecting with fellow village women. The CRs helped women to use radio both as a means of entertainment as well as a way of learning and educating oneself.

Accordingly, post analysis understanding can be summarized by stating that CR is the source of empowerment for women. It has changed the lives of women, for good, by giving them voice they never head and the courage to fight for their rights. It also helped them by creating awareness about various issues be it their rights, health issues, maternity issues, violence and education. It also made them adept with their political rights, voting rights, and reservations in Panchayati Raj institutions. CRs provide them the nerve to speak their heart out on issues important to them and to express their interests, by being anonymous, if they feel like. It gives them the confidence to live their life on their own terms. Thus, community radio does wonders on being used for the right cause and initiative as up-liftment of women.

\section{CONCLUSIONS}

On the whole, this paper enabled me to understand how community radios help addressing issues and concerns related to women. This study considered community radio stations for which women have been the main concern with respect to the programs they broadcast. From the aforementioned testimonies, it can be said that community radio is in no doubt an effective means for women to access information which is relevant to their lives and situations, and in most cases is normally denied or unavailable. Also, CR constitutes an opportunity for women to acquire a voice, which otherwise remains unheard. It is more democratic in its structure and functioning than the mainstream one. But it needs technical, financial and skill-base support from the policy makers in order to involve more and more people in the process of development and governance at the grass root level. Therefore, the government needs to revamp its policy and attitude towards community media keeping in mind the diverse needs, interests, cultures and aspirations of different rural and 
isolated communities in the country.

\section{REFERENCES}

1. Bhatia, C. (2016, December). Democratizing the rural development in India: A case study of Radio Mewat. Journal of Content, Community and Communication, 4. Retrieved February 2019

2. Dutta, D. A., \& Ray, D. A. (n. d.). Community Radio in North East. Retrieved February 2019

3. Gaur, S. (2016, July 15). Challenging Notions on Women Participation: Community Radio in India. Retrieved February 2019 , from Huffington Post: https://www.huffingtonpost.in/suchi-gaur-/challenging-notions-on-wo_b_6395292.html

4. Malik, K. K., \& Bandelli, D. (2012, November). Community Radio and Gender - Towards an Inclusive Public Sphere. Retrieved February 2019, from Researchgate.

5. Nirmala, Y. (2015, December 1). The Role of Community Radio in Empowering Women in India. Media Asia, 42. Retrieved February 2019

6. Rikzana, A. A., \& Neelamalar, M. (2015). The Role of Community Radio in Women's Empowerment: Case Studies from Developing Countries. Advances in Computer Science and Information Technology, 2(13). Retrieved February 2019

7. Al Mamun, Abdullah., Haque, A., Alam, S., \& Sultana, R. Minimization of Health and Environmental Hazards of Tobacco among the Folk Community in Rural Bangladesh.

8. Young India. (2017). Community Radio for Change. Action Aid. Retrieved February 2019 
